\title{
Optimizing Beef Cattle Nutrition from Conception to Consumption
}

\section{Patrick Gunn ${ }^{1}$}

\begin{abstract}
Feed cost and reproductive efficiency are the $1^{\text {st }}$ and $2^{\text {nd }}$ largest factors, respectively, that dictate profitability of the cow-calf enterprise. It should not be forgotten that these two economic areas are not independent of one another, as nutritional management is the largest single factor that producers can control that influences the probability of pregnancy. Thus, without proper nutritional management, many reproductive processes are altered, and establishment and maintenance of pregnancy may be hindered or prevented entirely. Traditionally, the major concern related to the interface between nutrition and reproduction is the effect of under nutrition prior to breeding. However, recent research in the fields of fetal/developmental programming as well as post-breeding heifer management suggests nutrition can significantly impact not only reproductive capacity of the female, but long term growth and efficiency of her progeny. Therefore, developing appropriate nutritional programs for all phases of production is critical for the economic success and productivity of the beef operation for not only the current year, but for years to come.
\end{abstract}

Keywords: Cow-calf, developmental programming, reproduction.

\section{Optimización de la Nutrición de Ganado de Carne de Concepción hasta Consumo}

Resumen. El costo del alimento y de la eficiencia reproductiva son los factores más importantes para dictar la rentabilidad de una empresa ganadera de crianza. No se debe olvidar que estas dos áreas económicas no son independientes una de otra, ya que el manejo nutricional es el factor más importante que los productores pueden controlar y que tiene influencia sobre la probabilidad de preñez. Por esto, sin un manejo apropiado de la nutrición, muchos procesos reproductivos pueden alterarse y el establecimiento y mantenimiento de la preñez puede ser afectada o completamente prevenida. Tradicionalmente, la mayor preocupación relacionada a la interfase entre nutrición y reproducción es el efecto de la subnutrición antes de la reproducción. No obstante, investigación reciente en los campos de programación fetal y de desarrollo al igual que manejo de vaquillas post-reproducción puede causar un impacto importante no solo en la capacidad reproductiva de la hembra, pero también el crecimiento a largo plazo y la eficiencia de su progenie. Por esto, el desarrollo de programas nutricionales apropiados para todas las fases de producción es crítico para el éxito económico y la productividad de la operación no solo para el año corriente, pero para los próximos años.

Palabras clave: Programación del desarrollo, reproducción, ternero, vaca.

\section{Nutritional Factors Affecting Reproduction}

Nutrition in the cowherd, while paramount to reproductive efficiency in all classes of females, is particularly vital to reproductive success in first-calf heifers. The primary reason for this is the economic losses associated with failure to conceive in these young females. Although a significant amount of resources are devoted to development of the yearling female, the ability to market open yearlings through the feedlot often gives producers the ability to recuperate the developmental costs of these females.
Conversely, as break-even of suckled cows does not occur until 5-7 years of age in most markets, failure to properly manage these younger cows represents the larger risk to enterprise profitability.

It is well established that reproductive efficiency is the main factor influencing production efficiency of a cow/calf operation (Short et al. 1990), with the failure of cows conceiving contributing to the largest loss of potential calves (Wiltbank et al. 1961). The factor that most impacts the likelihood of conception during a finite breeding period is the duration of the postpartum

\footnotetext{
${ }^{1}$ Department of Animal Science, lowa State University, Ames, lowa, 50011, Estados Unidos. Email: pgunn@iastate.edu
} 
anestrous (Wiltbank 1970). Therefore, a major constraint to reproductive efficiency in a beef herd is the duration between calving and the resumption of normal estrous cycles and ovulation, referred to as the postpartum interval. To maintain a 12-month calving interval, a cow must conceive within 80 to 85 days of calving. If the interval from calving until resumption of normal estrous cycles is extended past 85 days, the calving interval will be extended and economic productivity of the cow herd will suffer.
Nutritional effects on the duration of the postpartum period are multifaceted and influenced by a complex interplay between such factors at quantity and quality of feed, nutrient reserves stored in the body, level of milk production, and competition for nutrients from other physiological functions, besides reproduction (Short et al. 1990). The nutritional requirements for beef females in various stages of production are in Table 1.

Table 1. Comparison of nutrient requirements for gestating yearling heifers and mature cows as well as for 2-yearold and mature lactating cows $\mathrm{s}^{\mathrm{a}, \mathrm{b}}$

\begin{tabular}{|c|c|c|c|c|c|c|}
\hline \multirow[b]{2}{*}{ Stage of production } & \multirow{2}{*}{$\begin{array}{c}\text { Dry } \\
\text { matter } \\
\text { intake, } \\
\text { kg/day }\end{array}$} & \multirow{2}{*}{$\begin{array}{c}\text { Total } \\
\text { digestible } \\
\text { nutrients, } \\
\% \mathrm{DM}^{\mathrm{c}} \\
\end{array}$} & \multirow{2}{*}{$\begin{array}{c}\mathrm{NE}_{\mathrm{m}}{ }^{\mathrm{d}} \\
\mathrm{mcal} / \mathrm{kg} \\
\text { of DM }\end{array}$} & \multirow[b]{2}{*}{$\begin{array}{c}\text { Crude protein, } \\
\text { \% DM }\end{array}$} & \multicolumn{2}{|c|}{ Dry matter (\%) } \\
\hline & & & & & Calcium & Phosphorus \\
\hline $\begin{array}{l}\text { Gestating yearling, } \\
3^{\text {rd }} \text { trimester of } \\
\text { gestation }\end{array}$ & 11.5 & 56.0 & 0.64 & 8.45 & 0.30 & 0.22 \\
\hline $\begin{array}{l}\text { 2-year-old peak } \\
\text { lactation }\end{array}$ & 11.6 & 63.4 & 1.36 & 10.60 & 0.40 & 0.25 \\
\hline $\begin{array}{l}\text { Mature cow, } 3^{\text {rd }} \\
\text { trimester of gestation }\end{array}$ & 11.6 & 52.5 & 1.08 & 7.77 & 0.25 & 0.17 \\
\hline $\begin{array}{l}\text { Mature cow peak } \\
\text { lactation }\end{array}$ & 13.4 & 59.7 & 1.32 & 10.30 & 0.41 & 0.25 \\
\hline
\end{tabular}

Ripberger (1997) suggested that nutritional requirements for primiparous heifers may be greater than NRC requirements indicate, as they demonstrated that maintenance requirements for lactating 2-year-old Angus and Simmental cows were $23 \%$ and $39 \%$ greater than that for a mature lactating female, respectively. From a management standpoint, primiparous cows should be fed separately from multiparous females. Since the nutritional requirements for 2-year-old heifers are greater, they should have access to a greater quantity of higher quality feeds. Furthermore, social dominance and hierarchy cannot be ignored. Given their smaller stature, 2-year-old cows cannot compete with mature females for supplemented feeds, especially if bunk space is not adequate. Few studies have assessed the impact of nutritional manipulation on the postpartum interval, specifically in 2-year-old beef females. However, numerous articles are available on the relationship between nutritional inputs and postpartum reproductive function in beef cattle.

Regardless of the exact mechanism responsible, energy deficient diets delivered either prepartum and/or postpartum which results in losses in body weight and/or body fat, extends the postpartum anestrous interval in primiparous and multiparous cows, whereas, increasing the nutritional intake shortens the interval from calving until estrus and ovulation (Houghton et al. 1990, Randel 1990, Perry et al. 1991, Lalman et al. 2000). Furthermore, Perry et al. (1991) suggested that the amount of prepartum energy dictated when cows 
would ovulate following calving, while postpartum energy level determined whether or not cows would ovulate. In primiparous beef cows, Ciccioli et al. (2003) observed that the interval from calving until the resumption of normal estrous cycles was extended by 34 days in females fed to obtain moderate postpartum body weight gains ( $1 \mathrm{lb} /$ day) compared to cows fed to have greater body weight gains (2 lb/day). A similar relationship between postpartum energy level and duration of postpartum anestrus in primiparous cows was reported by Lalman et al. (2000).

Pre- and postpartum dietary restriction not only increases the postpartum interval but can result in a reduction in first service and breeding season pregnancy rates. Randel (1990) summarized the literature on the impact of pre- and postpartum energy and protein delivery on pregnancy rates in lactating beef cows (Table 2). Randel's review of the literature suggests that regardless of when inadequate energy and protein delivery was administered (pre- or postpartum); pregnancy rates in the subsequent breeding season were substantially reduced. Similarly, Houghton et al. (1990) reported that high postpartum energy intake in multiparous beef cows resulted in an improved pregnancy rate compared with cows receiving a low energy postpartum diet. The reason for the reduction in breeding season pregnancy rate in nutrient deficient females is multifactorial. First, given the extended period of postpartum anestrous, within a defined breeding season, fewer cows will exhibit estrous prior to cessation of the breeding period. Second, underfeeding and having the female in a state of negative energy balance may negatively impact the ability of the female to conceive and maintain the pregnancy (Leroy et al. 2008).

Table 2. Influence of dietary energy and protein on pregnancy rates in lactating beef cows and heifers (references for citations in table available in Randel 1990).

\begin{tabular}{|c|c|c|c|}
\hline $\begin{array}{l}\text { Energy Status } \\
\text { Adequate (\%) }\end{array}$ & Inadequate (\%) & $P$ - value & Source \\
\hline \multicolumn{4}{|c|}{ 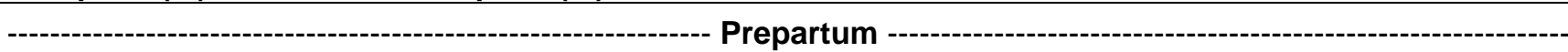 } \\
\hline $\begin{array}{l}68 \\
78\end{array}$ & $\begin{array}{l}60 \\
60\end{array}$ & $\begin{array}{l}<0.05 \\
0.10\end{array}$ & $\begin{array}{l}\text { Dunn et al. } 1969 \\
\text { Bellows and Short } 1978\end{array}$ \\
\hline 95 & 50 & $\begin{array}{l}\text { stpartum } \\
<0.01\end{array}$ & Wiltbank et al. 1962 \\
\hline 92 & 72 & $>0.05$ & Wiltbank et al. 1964 \\
\hline 87 & 64 & $<0.01$ & Dunn et al. 1969 \\
\hline 92 & 76 & $<0.05$ & Richards et al. 1986 \\
\hline \multicolumn{4}{|l|}{ Protein Status } \\
\hline & & repartum -- & \\
\hline 85 & 71 & $<0.11$ & Wettemann et al. 1980 \\
\hline 92 & 76 & $>0.10$ & Rasby et al. 1982 \\
\hline 58 & 21 & $<0.02$ & Mabley et al. 1983 \\
\hline 84 & 12 & $<0.01$ & Garmendia et al. 1984 \\
\hline 88 & 56 & $<0.11$ & Fleck and Lusby 1986 \\
\hline 94 & 44 & $\begin{array}{l}\text { stpartu } \\
<0.05\end{array}$ & Foero et al. 1980 \\
\hline 96 & 82 & $<0.03$ & Cantrell et al. 1982 \\
\hline 91 & 71 & $<0.01$ & Kropp et al. 1983 \\
\hline 92 & 77 & $<0.01$ & Hancock et al. 1984 \\
\hline 95 & 80 & $<0.01$ & Hancock et al. 1985 \\
\hline 79 & 50 & $<0.01$ & Rakestraw et al. 1986 \\
\hline 87 & 65 & $>0.10$ & Rakestraw et al. 1986 \\
\hline 89 & 85 & $>0.10$ & Rakestraw et al. 1986 \\
\hline
\end{tabular}


In addition to extending the postpartum interval and reducing pregnancy rates, deficient pre- and postpartum nutrition can reduce calf birth weights, milk production of the dam and weight gain of her progeny (Houghton et al. 1990, Spitzer et al. 1995; Lalman et al. 2000; Ciccioli et al. 2003). Lalman et al. (2000) suggested that primiparous beef cows fed a highenergy diet following calving were able to partition a greater proportion of net energy (consumed) to grow maternal tissues than cows on a moderate-energy diet. Birth weights of calves from cows fed an energy restricted diet have been demonstrated to be reduced compared to calves from cows fed an adequate diet (Perry et al. 1991).

Although much attention has been focused on reproductive efficiency as a result of pre- and postpartum nutrition, more research has been directed towards the effects of post-breeding nutrition on pregnancy success. In yearling heifers, Arias et al. (2013) and Perry et al. (2013) reported decreased conception rates to artificial insemination (Al) in females that experienced a reduction in dietary energy for as few as 7 days immediately following breeding. They hypothesize that when females are turned out on pasture within a few days following $\mathrm{Al}$, they may not consume the needed amount of dry matter, and thus calories, to support early embryo development. Whether this is due to adjustment to a new environment or early spring grass being too high in moisture to support sufficient dry matter intake is not certain. However, this concept raises an interesting question as to whether or not first-calf heifers and mature cows experience a similar shortage of energy intake if moved from a drylot to pasture soon after being bred. Although more research is needed in this area, these heifer data reinforce the idea that reproductive success is maximized when nutritional requirements are met in all stages of the production.

\section{Practical Methods to Assess and Manage Beef Female Nutrition}

Reproductive performance of beef females is closely linked to the amount of available energy, though feed consumed and energy reserves, available to the cow. In cattle, prepartum and postpartum nutrition is reflected by her amount of body fat. The most practical method to estimate the energy reserves and body fat of cows is by evaluating body condition scores (BCS). BCS are based on a numeric scale of 1 to 9, with cows scoring 1 being extremely thin or emaciated and 9 being obese. For optimal reproductive performance during the subsequent breeding season, mature cows should be between a BCS of 5.0 and 5.5 at calving. However, given that primiparous cows have increased stress due to additional nutrient requirements needed for continued growth (Table 1) and in many scenarios the primiparous 2-year-old heifer will lose body condition following calving during her first lactation, they should have a BCS of 5.5 to 6.0 at calving to ensure a BCS of 5.0 to 5.5 at breeding. Frequently assessing BCS during gestation is critical. As pregnancy proceeds, the nutritional requirement for both net energy and crude protein increase to support fetal and placental growth.

Environmental stressors such as extreme cold, wind chill and/or wet weather further add to the nutritional requirements of the beef herd. If intake of energy and/or protein is below that required to meet the cow's needs for maintenance, pregnancy or lactation, and environmental stress, cows will try to compensate by mobilizing stored energy (body fat) and will therefore lose body condition. Following calving, the nutritional requirements again increase to support lactation and repair of the reproductive tract. Therefore, if cows are thin at calving, due to submaintenance energy intake during late gestation, the increased demand for energy and protein to support lactation will make it even more difficult and expensive to adjust body condition between calving and the beginning of the breeding season. Thus, it is critical that the body condition monitored and adjusted prior to calving to ensure that adequate nutrition is delivered and that cows are in proper condition by calving. If cows are thin prior to calving, supplementation is necessary to regain body condition. As a general rule of thumb, it will take $80 \mathrm{lb}$ of body weight gain for a mature cow and $150 \mathrm{lb}$ of gain for a first-calf heifer to gain $1 \mathrm{BCS}$. However, this estimate does not take into account the additional nutritional requirements needed to support the advancing pregnancy. Providing additional nutrients during this period can increase costs; however, this additional nutrition is needed to ensure optimal reproductive performance.

Failing to achieve an adequate BCS at calving can negatively impact various aspects of reproductive performance. As BCS at calving decreases, postpartum interval increases (Table 3). Furthermore, in a recent multistate study, Larson et al. (2006) reported that for every one point increase in BCS an additional 
$12 \%$ of the cows were cyclic at the start of the breeding season. Because BCS is reflective of nutritional status of the female and, as summarized above, nutrient deficient females have extended postpartum intervals, these data are not surprising. To achieve a 365 day calving interval, females must conceive within 85 days following calving. Therefore, this management goal is difficult to achieve in under-nourished cattle, especially in first-calf heifers. Given this challenge of achieving a 365 day calving interval, it is recommended that yearling heifers begin the breeding season three to four weeks prior to the mature cows. This will allow for additional time following calving for the first lactation heifer to resume estrous cycles and have a greater probability of conceiving in a timely manner during the subsequent breeding season.

Table 3. Effect of body condition score (BCS) at calving on postpartum interval ${ }^{\mathrm{a}}$.

\begin{tabular}{cc}
\hline BCS & Postpartum Interval $^{\mathbf{b}}$ \\
\hline 3 & 88.5 \\
4 & 69.7 \\
5 & 59.4 \\
6 & 51.7 \\
7 & 30.6 \\
\hline
\end{tabular}

${ }^{a}$ Adapted from Houghton et al. 1990

${ }^{\mathrm{b}}$ Average day post-calving when cows resumed normal estrous cycles.

Collectively, data demonstrate that thin cows take longer to exhibit estrus following calving, resulting in an extended calving interval and a failure to achieve one calf per cow every 12 months. Moreover, an extended postpartum interval due to inadequate body condition also results in fewer cows returning to estrus during the breeding season, ultimately resulting in fewer cows getting pregnant. This is illustrated in Figure 1, which shows the percentage of cows that became pregnant in six research herds (four states) and includes both mature and 2-year-old cows. These results clearly indicate that BCS at calving influences the percentage of cows getting pregnant in the subsequent 60 to 90 day breeding season. These results and numerous others conclusively demonstrate that cows in poor body condition at calving have poorer reproductive performance in the subsequent breeding season.

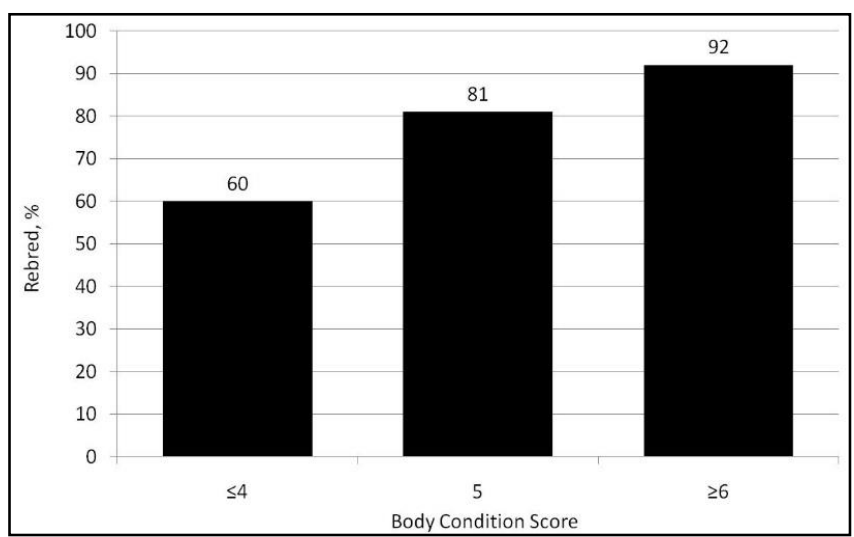

Figure 1. Percent of cows pregnant the subsequent breeding season according to BCS at calving. Adapted from Selk 2010 (ANSI-3283).

\section{Developmental Programming}

In addition to affecting reproductive performance, cow nutrition also affects the performance of her calf through a myriad of avenues. Initially based on epidemiological data in humans, the Barker hypothesis, or Barker theory suggests that alterations in environment such as nutrition, stress, or disease during critical time points in development, such as fetal or early neonatal life, can have a significant impact of future growth, development and risk of disease (Barker 1994). Through this hypothesis, it can be concluded that insults during early development are a direct reflection of alterations in maternal environment, which are then imposed on the fetus or neonate, potentially resulting in an altered phenotype of the offspring.

As it relates to food animal production, the concept of developmental programming is relatively new. In most cases, resulting progeny of undernourished animals have reduced birth weight and often express poor postnatal growth rates (Greenwood et al. 2000 and 2004, Ford et al. 2007), increased morbidity (Garite et al. 2004), increased proportion of body fat in relation to lean (Greenwood et al. 2000, Ford et al. 2007) metabolic disorders (Fowden et al. 2005, Ford et al. 2007), and alterations in organ function (Da Silva et al. 2002, Sullivan et al. 2009 and 2010, Echternkamp et al. 2012).

Cows in poor body condition at calving have smaller calves that are weaker and more susceptible to disease. Thin cows have both lower quality and 
quantity of colostrum and produce less milk during lactation (Perry et al. 1991, Lalman et al. 2000). These aforementioned factors ultimately result in reduced weaning weights of calves born to thin cows (Houghton et al. 1990). Furthermore, thin cows that get pregnant following an extended postpartum interval will have calves that are younger and smaller at weaning the following year. Taking into account the problems associated with thin cows at calving, as outlined above, the economic ramifications can be substantial.

Although not well noted in beef literature, many other species have reported that maternal nutrition can also impact puberty and lifetime reproductive efficiency (Guzman et al. 2006, Long et al. 2010). Maternal protein supplementation has been shown to increase the probability of female beef progeny reaching puberty prior to the first breeding season (Funston et al. 2008). Specifically, a greater proportion of heifers born to cows that grazed winter range and were supplemented with a $28 \%$ crude protein supplement three times weekly during late gestation were pubertal at initiation of the breeding season when compared with progeny of cows not receiving a supplement. In another study from the same laboratory, protein supplementation ( $0.45 \mathrm{~kg} / \mathrm{d}$ of a $42 \%$ crude protein supplement) fed to cows grazing winter range during late gestation produced heifer progeny that had greater pregnancy rates during their first breeding season and calved earlier during their first calving season (Martin et al. 2007). In a similar manner, heifers born to mature cows ( $\geq 3$ years of age) fed $125 \%$ of nutritional maintenance requirements during the third trimester of gestation conceived earlier in their first breeding season than those born to dams fed either 75 or $100 \%$ of nutritional maintenance requirements during that period (Cushman et al. (2012).

While reproductive development and efficiency may be influenced in the offspring of nutritionally altered dams, we know that epigenetic modifications to the genome are heritable, and therefore alterations in reproductive capacity may not be relegated to the first generation. Blair et al. (2010) reported a transgenerational effect of maternal nutrition on reproductive capacity where fewer grand-offspring resulting from lightweight ewes given ad-libitum access to feed (over-nourished) during early pregnancy reached puberty prior to their first breeding season when compared with lightweight grand-dams that were limit fed or heavyweight grand-dams regardless of nutrition.
In addition to altered reproductive development in progeny as a result of fetal environment, it is imperative overlooked that the same fetal stressors may elicit changes in steer progeny growth and carcass characteristics. However, data suggest that changes in growth and carcass quality are dependent on timing of the maternal nutritional insult. Specifically, Underwood et al. (2010) reported increases in steak tenderness, 12th rib fat thickness, and adipose cells numbers in the longissimus muscle of steers resulting from cows grazing higher quality pasture between 120 and 210 days of gestation. In another study from the same laboratory, cows that were nutrient restricted from 45 to 185 days of gestation gave birth to calves that had greater adipocyte diameter at the subcutaneous, perirenal, mesenteric, and omental depots at slaughter (Long et al. 2012). These data would suggest that maternal dietary manipulation during early- to mid-gestation has the potential to alter carcass composition and meat quality. In contrast to the under nutrition models, recent studies have explored the effects of alternative energy sources during the last trimester of pregnancy on progeny feedlot performance and carcass characteristics, but data are inconclusive. Collectively, these data suggest that carcass composition can indeed be altered in steers born to dams that were undernourished during early- and mid-gestation; however, the effects of maternal nutrition during late gestation on offspring feedlot performance and carcass characteristics require further experimentation.

\section{Economics of Proper Nutrition}

The impact that BCS at calving has on reproductive efficiency, calf performance, and farm income is in Table 4. Thin cows (BCS 3, and 4) have reduced pregnancy rates, increased calving intervals, wean a younger/lighter calf, and provide considerably less yearly income compared to cows that are in good condition (BCS 5, and 6) at calving. Therefore, the extra expense of supplemental feeds to improve prepartum BCS is recaptured and typically exceeded by the yearly profitability of the cows. The improvement in reproductive efficiency of cows maintained in good body condition is substantial; however, level of increased income (profitability) from improving BCS will vary depending upon several factors, most notably feed costs. 


\section{Take Home Message}

Nutrient management of beef cows is critical to maximize reproductive efficiency and subsequent economic viability of the beef operation. First-calf females have greater nutritional requirements than multiparous cows, and thus should be fed accordingly and preferably separate from the mature cow herd to ensure adequate nutritional intake. Furthermore, failing to provide sufficient nutrition either pre- and/or postpartum to any group of females may likely result in an increased postpartum interval and reduced pregnancy rates. It is also critical to realize that proper nutritional programming may begin in utero. Thus, failure to provide adequate nutritional stimulation at any phase of production could have lasting negative impacts on reproductive efficiency of the herd.

Table 4. Relationship of body condition score (BCS) to beef cow performance and income (Adapted from Kunkle et al. 1998 UF/IFAS Publication SP-144).

\begin{tabular}{|c|c|c|c|c|c|c|c|c|}
\hline $\mathrm{BCS}^{\mathrm{a}}$ & $\begin{array}{c}\text { Pregnancy } \\
\text { Rate, } \%^{\mathrm{b}}\end{array}$ & $\begin{array}{c}\text { Calving } \\
\text { Interval, } \\
\text { days }\end{array}$ & $\begin{array}{c}\text { Calf } \\
\text { Weaning } \\
\text { Age, } \\
\text { days }^{c}\end{array}$ & $\begin{array}{c}\text { Calf } \\
\text { Average } \\
\text { Daily } \\
\text { Gain, Ib }\end{array}$ & $\begin{array}{c}\text { Calf } \\
\mathbf{w W}, \mathbf{I b}^{\mathrm{d}}\end{array}$ & $\begin{array}{c}\text { Calf } \\
\text { Price } \\
\$ / 100 \\
\text { lb }^{\mathrm{e}} \\
\end{array}$ & $\begin{array}{l}\text { Income } \\
\$ / \text { Calf }\end{array}$ & $\begin{array}{l}\text { Yearly } \\
\text { Income } \\
\$ / \text { Cow }^{g}\end{array}$ \\
\hline 3 & 43 & 414 & 190 & 1.60 & 374 & 320 & 1197 & 474 \\
\hline 4 & 61 & 381 & 223 & 1.75 & 460 & 295 & 1357 & 762 \\
\hline 5 & 86 & 364 & 240 & 1.85 & 514 & 279 & 1434 & 1134 \\
\hline 6 & 93 & 364 & 240 & 1.85 & 514 & 279 & 1434 & 1227 \\
\hline
\end{tabular}

a Body Condition Score: scale of 1 (thin) to 9 (obese).

b Pregnancy rates averaged across trials in Texas, Oklahoma, and Florida when BCS was assessed at calving, breeding, and pregnancy testing.

${ }^{c}$ Weaning age; 240 days for cows in BCS of 5 and 6 and decreases as calving intervals increase.

d Adjusted Weaning Weight; calculated as calf age times calf gain plus birth weight $(70 \mathrm{lb})$.

e Average price for similar weight calves during November 2014. Price will vary depending upon market conditions.

${ }^{f}$ Calculated as calf weight times calf price.

${ }^{9}$ Calculated as income/calf times pregnancy rate times 0.92 (\% survivability i.e. \% calves raised of those that became pregnant).

\section{References Cited}

Arias, R.P., P.J. Gunn, R.P. Lemenager, G.A. Perry, G.A. Bridges, and S.L. Lake. 2013. Effects of post-Al nutrition in fertility of yearling beef heifers. Proceedings of the Western Section American Society of Animal Science p. 64.

Barker, D.J.P. 1994. Mothers, babies, and diseases later in life. British Medical Journal Publishing Group, London.
Blair, H.T., C.M.C. Jenkinson, S.W. Peterson, P.R. Kenyon, D.S. van der Linden, L.C. Davenport, D.D.S. Mackenzie, S.T. Morris, and E.C. Firth. 2010. Dam and granddam feeding during pregnancy in sheep affects milk supply in offspring and reproductive performance in grandoffspring. Journal of Animal Science 88 (E. Suppl.):E40E50.

Ciccioli, N.H., R.P. Wettemann, L.J. Spicer, C.A. Lents, F.J. White, and D.H. Keisler. 2003. Influence of body condition at calving and postpartum nutrition on endocrine function and reproductive performance of primiparous beef cows. Journal of Animal Science 81:3107. 
Cushman, R.A., A.K. McNeel, and H.C. Freetly. 2012. The impact of cow nutrient status during the second and third trimester on development of the reproductive axis and fertility of daughters. Journal of Animal Science 90(ESuppl. 1): (Abstr.).

Da Silva, P., R.P. Aitken, S.M. Rhind, P.A. Racey, and J.M. Wallace. 2002. Impact of maternal nutrition during pregnancy on pituitary gonadotrophin gene expression and ovarian development in growth-restricted and normally grown late gestation sheep fetuses. Reproduction 123:769-777.

Echternkamp, S.E., D.R. Eborn, and R.A. Cushman. 2012. Reduced fertility in female progeny from beef heifers on dietary restriction during development. Journal of Animal Science 90 (E-Suppl. 1): (Abstr.).

Ford, S.P., B.W. Hess, M.M. Schwope, M.J. Nijland, J.S. Gilbert, K.A. Vonnahme, W.J. Means, H. Han, and P.W. Nathanielsz. 2007. Maternal undernutrition during early to mid-gestation in the ewe results in altered growth, adiposity, and glucose tolerance in male offspring. Journal of Animal Science 85:1285-1294.

Fowden, A.L., D.A. Giussani, and A.J. Forhead. 2005. Endocrine and metabolic programming during intrauterine development. Early Human Development 81:723-734.

Funston, R.N., J.L. Martin, D.C. Adams, and D.M. Larson. 2008. Effects of winter grazing system and supplementation during late gestation on performance of beef cows and progeny. Proceedings of the Western Section American Society of Animal Science 59:102-105.

Garite, T.J., R. Clark, and J.A. Thorp. 2004. Intrauterine growth restriction increases morbidity and mortality among premature neonates. American Journal of Obstetrics and Gynecology 191(2):481-7.

Greenwood, P.L., A.S. Hunt, J.W. Hermanson, and A.W. Bell. 2000. Effects of birth weight and postnatal nutrition on neonatal sheep: II. Skeletal muscle growth and development. Journal of Animal Science 78:50-61.

Greenwood, P.L., H. Hearnshaw, L.M. Cafe, D.W. Hennessy, and G.S. Harper. 2004. Nutrition in utero and pre-weaning has long term consequences for growth and size of Piedmontese and Wagyu-sired steers. Journal of Animal Science 82 (Suppl.1): 408. (Abstr.)

Guzman, C., R. Cabrera, M. Cardenas, F. Larrea, P.W. Nathanielsz, and e. Zambrano. 2006. Protein restriction during fetal and neonatal development in the rat alters reproductive function and accelerates reproductive ageing in female progeny. Journal of Physiology 572:97108.

Houghton, P.L., R.P. Lemenager, L.A. Horstman, K.S. Hendrix, and G.E. Moss. 1990. Effects of body composition, pre- and postpartum energy level and early weaning on reproductive performance of beef cows and preweaning calf gain. Journal of Animal Science $68: 1438$.
Kunkle, WE, RS Sands, and D.O. Rae. 1998. Effects of body condition on productivity in beef cattle. Department of Animal Sciences, Florida Cooperative Extension Service, UF/IFAS. SP-144.

Lalman, D.L., J.E. Williams, B.W. Hess, M.G. Thomas, and D.H. Keisler. 2000. Effect of dietary energy intake on milk production and metabolic hormones in thin, primiparous beef heifers. Journal of Animal Science 78:530.

Leroy, JL., A. Van Soom, G. Opsomer, I.G. Goovaerts, and P.E. Bols. 2008. Reduced fertility in high-yielding dairy cows: are the oocytes and embryos in danger? Part II. Mechanims linking nutrition and reduced oocyte and embryo quality in high-yielding dairy cows. Domestic Animal Reproduction. 43:623.

Long, N.M., M.J. Nijland, P.W. Nathanielsz, and S.P. Ford. 2010. The effect of mid gestational nutrient restriction on female offspring fertility and hypothalamic-pituitaryadrenal axis response to stress. Journal of Animal Science 88:2029-2037.

Martin, J.L., A.S. Cupp, R.J. Rasby, Z.C. Hall, and R.N. Funston. 2007. Utilization of dried distillers grains for developing beef heifers. Journal of Animal Science 85:2298-2303.

NRC. 2000. Nutrient Requirements of Beef Cattle. 7th rev. ed. Natl. Acad. Press, Washington, DC.

Perry, R.C., L.R. Corah, R.C. Cochran, W.E. Beal, J.S. Stevenson, J.E. minton, D.D. Simms, and J.R. Brethour. 1991. Influence of dietary energy on follicular development, serum gonadotropins, and first postpartum ovulation in suckled beef cows. Journal of Animal Science 69:3762.

Perry, G.A., B.L. Perry, J.A. Walker, C.L. Wright, R.R. Salverson, and H.H. Patterson. 2013. Evaluation of prior grazing experience on reproductive performance in beef heifers. Professional Animal Scientist 29:595-600.

Randel, R.D. 1990. Nutrition and postpartum rebreeding in cattle. Journal of Animal Science 68:853.

Ripberger, T.J. 1997. Determination of net energy requirements (NE maintenance and NE delta) of the primiparous heifer. M.S. Thesis. Purdue University.

Selk, G. 2010. Body condition scoring of beef cows. Oklahoma State University. Oklahoma Cooperative Extension Service Publication ANSI-3283.

Short, R.E., R.A. Bellows, R.B. Staigmiller, J.G. Berardinelli, and E.E. Custer. 1990. Physiological mechanisms controlling anestrus and infertility in postpartum beef cattle. Journal of Animal Science 68:799.

Spitzer, J.C., D.G. Morrison, R.P. Wettemann, and L.C. Faulkner. 1995. Reproductive responses and calf birth and weaning weights as affected by body condition at parturition and postpartum weight gain in primiparous beef cows. Journal of Animal Science 73:1251-1257. 
Sullivan, T.M., G.C. Micke, R. M. Greer, H.F. Irving-Rodgers, R.J. Rodgers, and V.E.A. Perry. 2009. Dietary manipulation of Bos indicus $x$ heifers during gestation affects the reproductive development of their heifer calves. Reproduction, Fertility, and Development. 21:773-784.

Sullivan, T.M., G.C. Micke, R.M. Greer, and V.E.A. Perry. 2010. Dietary manipulation of Bos indicus $x$ heifers during gestation affects the prepubertal reproductive development of their bull calves. Animal Reproduction Science 118:131-139.

Underwood, K.R., J.F. Tong, P.L. Price, A.J. Roberts, E.E. Grings, B.W. Hess, W.J. Means, and M. Du. 2010. Nutrition during mid to late gestation affects growth, adipose tissue deposition, and tenderness in cross-bred beef steers. Meat Science 2010 Nov;86(3):588-93. Epub 2010 Apr 28.
Wiltbank, J.N., E.J. Warwick, E.H. Vernon, and B.M. Priode. 1961. Factors affecting net calf crop in beef cattle. Journal of Animal Science 20:409.

Wiltbank, J.N. 1970. Research needs in beef cattle reproduction. Journal of Animal Science 31:755.

Received for publication on April 1, 2016.

Accepted for publication on July 7, 2016. 